\title{
Representing the Poetics of Place. A conversation with Steven Feld
}

Steven Feld and Katell Morand

\section{(2) OpenEdition \\ 1 Journals}

Electronic version

URL: https://journals.openedition.org/clo/8424

DOI: $10.4000 /$ clo.8424

ISSN: 2266-1816

Publisher

INALCO

\section{Printed version}

Date of publication: 30 June 2020

Number of pages: 89-98

ISBN: 978-2-85831-392-1

ISSN: 0396-891X

Electronic reference

Steven Feld and Katell Morand, "Representing the Poetics of Place. A conversation with Steven Feld", Cahiers de littérature orale [Online], 87 | 2020, Online since 16 September 2021, connection on 09

November 2022. URL: http://journals.openedition.org/clo/8424 ; DOI: https://doi.org/10.4000/clo.8424

\section{(c) $(1)(9$}

Creative Commons - Attribution-NonCommercial 4.0 International - CC BY-NC 4.0 https://creativecommons.org/licenses/by-nc/4.0/ 


\title{
Representing the Poetics of Place. A conversation with Steven Feld
}

\author{
Interview: Katell MoRAND
}

\begin{abstract}
"The juxtaposition of contrasting grammatical concepts may be compared with the so-called 'dynamic cutting' in film montage, a type of cutting, which, e.g, in Spottiswoode's definition, uses the juxtaposition of contrasting shots or sequences to generate in the mind of the spectator ideas that these shots or sequences by themselves do not carry."

Roman Jakobson $^{1}$
\end{abstract}

K.M: ${ }^{2}$ The poetics of place has been a central theme in your work since the 1970s. After years of doing fieldwork in Bosavi, Papua New Guinea, you introduced in 1993 in your influential essay "Waterfalls of song" the concept of "acoustemology," or sound as a way of knowing, ${ }^{3}$ and you analyzed in fine detail the linguistic and poetic features of the Bosavi acoustemology. As a way of introducing the French translation of this essay, I would like to focus on the poetic performances of the Bosavi people: what they tell of a way of being in the world, and how you have chosen to translate and represent them through texts,

1. Jakobson R., 1968, "Poetry of Grammar and Grammar of Poetry" in Verbal Art, Verbal Sign, Verbal Time, 37, p. 604.

2. I thank Loï Ponceau for his help in writing down the transcript of this interview.

3. Feld S., 1996, "Waterfalls of Song: An Acoustemology of Place Resounding in Bosavi, Papua New Guinea" in BAsso \& Feld (eds), Senses of Place, School of American Research Press, pp. 91-135. 
recordings, photographs, or films. Could you start for example by telling us how sensory features of the rainforest find their way into Bosavi poetics?

S.F: Before I worked on the details of Bosavi place and poetics, I was aware, from the work of Edward L. Schieffelin, ${ }^{4}$ that Bosavi songs were maps of the forest, and that they had many place names in them. Songs narrated the relationship between persons, exchanges, communities, family histories and the forest. My concern was to take a deeper look at the underlying linguistics: dimensions of linguistic iconicity, metaphor, and, in particular, poetic grammar, following Roman Jakobson's theorization of verbal art. This was for my Ph.D. project in the field of linguistic anthropology.

Jakobson's concept of poetic grammar asks: are there specific features of a language that only pertain to poetic formation? Which features of the everyday grammar can or can't move into the poetic? Which features of the poetic register are unique to song? Are these distinct from other narrative and non-narrative forms? Those were my linguistic questions. To answer I needed to attend to grammar and lexicon in general and its interplay in practice with the poetic lexicon and grammar. My dissertation covered such questions in detail; a summary appears as "The poetics of loss and abandonment," a chapter of Sound and Sentiment. ${ }^{5}$

In this chapter, I talked about how four metalinguistic concepts organize Bosavi poetics. "Speaking inside" is the idea of a language register with distinct intent from everyday pragmatics. "Turned-over words" is the Bosavi concept of metaphor. "Sound-words" is the use of ideophones, onomatopoeia, and iconic features of language. And the "path" of the song, central to its narrative form, implicates place names. In the one thousand songs that I recorded in twenty-five years of research, there are more than seven thousand place names. Sometimes, these songs have a very detailed list of the features between close places, taking the listener from one immediate location to another proximal one. And sometimes, these places can be far apart, less immediately continuous.

From the very beginning I could tell that Bosavi poetry requires a mastery of ecology, because the songs also name seventy-eight kinds of birds, one hundred and ten kinds of trees, and at least ninety different kinds of sounds

4. Schieffelin E., 1976, The Sorrow of the Lonely and the Burning of the Dancers, Palgrave Macmillan, New York, 244 p.

5. Feld S., 1982, Sound and Sentiment: Birds, Weeping, Poetics, and Song in Kaluli, University of Pennsylvania Press, Philadelphia, 264 p. 
of moving water, thirty kinds of sunlight, cloud formation and different kinds of light. This also takes us into ideophones, onomatopoeia, and iconicity. One can indicate dimensions of volume, size, distance, height, depth, and duration by the use of some four hundred "sound-words" in the Bosavi language. Poetics thus requires deep sensuous knowledge of the world, especially how it sounds. That's a way to both raise and answer some questions: why do the best local ornithologists also tend to be exceptional singers and composers? Why are people who have closely observed forest diversity so skilled in the poetic lexicon? Why is knowledge of waterways and water sounds necessary to train the voice of a singer?

For me, the stunning part was that poetic grammar and performance not only involve ecology, but also cosmology. All of these forest names are associated with ancestors: birds are what people become when they are no longer alive. The sounding, images, smells, tastes, sensations of the world of the forest are also the smells, sounds, tastes and visions of the spirit world. So: are cosmology and ecology "inside" grammar, and not simply a mirror, on the outside of it? For me, that is where the question of poetic language becomes even bigger than the way it was posed by Jakobson. What must I know about the sensory world to understand poetic grammar?

This was the work that I did in the seventies, and it served as a useful foundation when, in later times, multi-species approaches became critical for post-humanist anthropology. In Papua New Guinea, a person is always being completed by relations with others. There are not just human others, but spirit others, material others, non-human others. But they are never totalized as "others." This kind of theory is associated with people like Gregory Bateson, Marilyn Strathern, Annette Weiner, Nancy Munn, and Roy Wagner, people who did serious ethnographic work in Papua New Guinea. Their studies of gender, ritual, exchange, kinship, and materiality opened the door for me to develop an approach to poetics through sonic relationality and acoustic epistemology.

K.M: In the article, you analyze the performance of three songs by a woman named Ulahi. Reading these texts, I was struck by both the precision and obscurity of their narrative form. Is that because places are observed from the point of view of a bird, removed from ordinary perception? What makes such point of view?

S.F: In daily experience, Bosavi people can walk distances on forest paths. But their songs don't follow footpaths; they follow the waterways. Why? Because birds navigate the dense forest spaces by movement through waterways. The birds 
follow the flows that connect discontinuous places. So songs travel through the water, imagining the forest both from above and from mid-heights too. But of course there are a few birds that live on the ground. Bosavi people say they're just like the birds when they make a song: a bit of movement over land, like the path of place names a bird or person walks. But most of it is traveling through the waterways, through the creeks, the streams, the rivers, no matter how large or small. Of course, like humans, it's important that the birds pay attention to what is there. Where are the rocks, the trees, the obstacles, the dangers, the things that they can or can't eat, the places where they can or can't perch?

So the songs have to follow water the way a bird will do it; they go to the top of the forest as well as penetrate and move around in it. As Bosavi people explain, water is to the voice as land is to the body. To be a composer and a singer, one must simultaneously evoke the forest world from the point of view of the feet, of the mind, and of a bird journey, constantly fusing ecology and cosmology. To give you a banal example: there is no way for me to literally travel from Santa Fe, New Mexico, to Paris, France in six seconds. But I have the capacity to do it poetically: with iconics evoking images, smells, and tastes that make the transport immediate. Or I can simply start a song by singing "oui." Knowing this familiar word in the French language, you might ask yourself, internally: "this bird speaks my language, what is it saying to me?" And then you might begin to interpret the gesture: "is the Steve-bird in Paris?" Or: "is it dreaming of flying to Paris?" Or: "has it been here recently?" And "oui" in response to what question, what assertion, what provocation? At this point you will attend the place names that follow ever more carefully to ascertain the relations of past, present, and future space that poetically connect us as emplaced persons. So, one word can take you $8500 \mathrm{~km}$ with great speed and efficacy.

K.M: This constant interplay with the senses and the imagination makes translating these songs seem particularly difficult. How did the process go? Were there specific obstacles?

S.F: Well, it's a process where you try to do something with the skills that you have acquired, and when you realize it doesn't work, you do something else. For example, I would play back the song to the singer. We sat with headphones to transcribe and annotate the text. Then I realized that this had serious limits. So the next time I bring a Polaroid camera. We follow the "path" and for each place or evocative word we make an instant image. Then I lay them out like a narrative sequence with the text, trying a combined image-text-sound way to understand 
the "path." This is what I started doing in the seventies and the eighties. But as I am not a bird, nor a good tree climber, I also came to visual limits. So I returned to the text, this time just for the sensuous material. I find the name of a waterfall and then the word gululu. Then I need to relate this to the way that there are some two thousand words in the Bosavi language where the use of the vowel $u$ iconically marks the sound moving from above to below. Then I'll look at the alternation of $g$ and $l$ : why is this word gulu? And then why gululu? Can it be gulu gulu or lugu lugu? What works and what doesn't? Where does it naturally occur in song? This requires work on more songs with the same singer, and then work with others singers who live in the same territory and who share some similar maps or texts. Then you have the wonderful possibility to work with, not just the singer, but her brother, or children, and the songs he has made, the songs a daughter or son have made.

I had been doing these things for almost twenty years when I wrote "Waterfalls of Song." By then I understood quite a bit about listening to these paths, and especially the space-time travel capacities of phonesthesia. I understood that a singer like Ulahi has the world in her mouth. Using minimal sound contrast she could indicate precise or very dreamy things about space, motion, and duration. I also by then understood the difference between the use of verbal tense (past, present, future, etc.) in everyday speech and the use of aspect (durational, conditional, habitual, etc.) in the songs. Also by 1993, I had been up in a helicopter with Bosavi people, to put GPS markers on the place names of songs. With that "big picture" I started to understand how the songs also are a kind of land territory map joined to the politics of community history. It's endless, of course, but this is how "translation" led me from poetics to the layered density of ecology and cosmology forging senses of place.

K.M: This brings me to the way you wrote this text. There is a density to it. The flow to the text, and your own metaphors and play with sonorities seem to echo that of the Bosavi. Was there the idea that your writing process should mirror the Bosavi ways of listening or composing?

S.F: Yes. There are two important factors here. The first one is the state of my fieldwork at that time. In 1990, I made a research trip to record the Voices of the Rainforest $\mathrm{CD},{ }^{6}$ including the three songs by Ulahi discussed in this text.

6. Feld S., 1991, Voices of the Rainforest: A Day in the Life of the Kaluli People, CD. The World series, Mickey Hart, ed. Rykodisc, Boston. 
I returned with the published CD in 1992, which gave me the possibility to follow up on many details. Then I drafted the paper in 1993, and the "Senses of Place" conference took place during a week later in that year. I went back to Bosavi in 1994 to refine the analyses yet again and edit a final version for the book, published in 1996. It was a time of deep intellectual excitement for me, both the fieldwork and re-reading Jakobson, Merleau-Ponty, Bateson. And of course the conference. My essay profited from very generous responses from Edward Casey, Katie Stewart, Nancy Munn, Clifford Geertz, and especially from co-organizer and co-editor Keith Basso, who was a brilliant linguist and ethnographer, at that time writing Wisdom Sits in Places. ${ }^{7}$ So this is the context for the invention of acoustemology.

It was Keith who encouraged me to write something that was as dense as the forest, but with gentle spaces, as gentle as Ulahi's voice. Luckily I was helped in this by Voices of the Rainforest, already well in circulation. My readers were able to hear what I was writing about. On the CD they could hear the forest, the birds, the insects in the trees, the whole world Ulahi was listening to, singing with, and singing about.

K.M: You did a very unique work for that 1991 recording, using different microphones, and placing them at different forest heights and depths to give a sense of what Bosavi people really perceive when listening. Then you went back in 2018 to make a new film. In it, we hear again the same performance of Ulahi singing. Why did you do this movie at this point? What is the purpose of adding old and new pictures to the sound of Ulahi's voice at the creek?

S.F: For me, research is a book with no back cover. When you have done a great deal of fieldwork, you know how every answer becomes a new question. I was very pleased with the popular success of the $C D$, and of course, through Mickey Hart, pleased to have access to fantastic technology and engineers to help me articulate my ideas. In 2015 I told Mickey that for the $25^{\text {th }}$ anniversary I wanted to digitize the original analog tape recordings and to recompose the piece in the cinematic format of 7.1 sound, to make a 360 degree immersive experience of the rainforest as a concert for galleries, museums, theater, or acousmonium. That led to spending one year at Skywalker Sound, George Lucas'

7. Basso K. H., 1996, Wisdom Sits in Places: Landscape and Language Among the Western Apache, University of New Mexico Press, Albuquerque, 192 p. 
sound facility in California. I worked with Dennis Leonard, a distinguished film sound designer and we made a cinema for the ears, a cinematic representation of the sound world of the forest. I toured the world with that and then money became available to create a visualization of that soundtrack. So in 2018 I went back to Bosavi with filmmaker Jeremiah Richards. We spent two months with the people and showed them old images, played the sound, and discussed the images. And I had a fantastic reunion, after eighteen years, with Ulahi, still active as a composer. At the end of 2019 the project was published as a one hundred fifty page photographic book, with both a second edition of the CD and a Blu-ray disc with the 7.1 surround sound film ${ }^{8}$.

K.M: From what I understand, you have been creative every step along the way, trying to best represent Bosavi ways of listening. Is that what is happening? Trying to refine not only your knowledge, but also the many ways you could translate it?

S.F: Yes. I have always said that my methodology for acoustemology is "listening to histories of listening." When we hear Ulahi singing at the creek, we are not just hearing her create a composition. We are listening in to her history of listening. What does it take for me, who has the privilege of a certain closeness to this world, to then make it possible for you to have not only an intellectual, abstract experience of it, but also some kind of more personal, emotional, sensuous, aesthetic experience too? For this the film shows the newest translation attempt, based on Ulahi explaining to me how the song follows the bird's perspective, with her own way of apprehending and imagining the forest. The very first word of the song, "seyago," the bird-singer's name, is heard over a split screen image that juxtaposes a still image of the bird, a still image of the named tree from where the bird sings, and, below, a moving image of the flowing water just in front of Ulahi's feet as she sings. The use of experimental imaging and editing techniques here recall exactly Jakobson's analogy between dynamic cutting and grammatical juxtapositions to produce the self-referential gestalt shift he termed "poesis."

8. Feld S., Leonard D. \& Ra Richards J., 2019, Voices of the Rainforest: A Day in the Life of Bosavi, Papua New Guinea. Audio $2^{\text {nd }}$ edition CD, BluRay 7.1 film with Concert and Ambient programs, and photographic book, VoxLox/Bosavi Peoples Fund, Santa Fe, NM. 
What is methodologically most important for me is that I still continue to refine, within the notion of a "history of listening," the technique of "dialogic editing." I take these images, and I combine them in different ways, the same way I did with Polaroid pictures, thirty years before, but always the critical part is the conversation with Ulahi. For me poetic translation involves more than having both a microscope and a telescope; it requires dialogic editing, and inter-vocal intimacy.

K.M: How different is it today coming back to Bosavi? Are there changes in the ecological setting and in the way people think? In "Waterfalls of Song" you wrote that men stopped singing gisalo, and that Ulahi was taking on that tradition.

S.F: The 1990s were a period of great instability for Bosavi people, which led to the suspension of my returns from 2000. Logging companies were trying to get access to the forest. Oil was discovered and developed twenty-five miles away from Bosavi. Twenty years of evangelical missionaries, from 1970 to 1990, had a terrible impact, diminishing pride in Bosavi culture. By the new millennium there was great confusion, and I didn't expect to hear a ceremonial song ever again. But the songs of work, of everyday relations with the forest and the spirit world were very strong.

The other thing about that period is that genre and gender relations changed profoundly. Young people developed skills with ukulele and guitars as the result of going to a new school. For the first time, young men and women were making music together. Everything was being reconfigured. Men were going to the outside world to look for work; that left younger people and women at the creative center of village activity. This was the moment when Ulahi became a star. During the nineteen seventies and eighties, I never thought such a thing would happen. But when I came back from Bosavi in 1990, and played the new tape recordings for Mickey Hart, he agreed instantly that Voices of the Rainforest, soon to be the first world distribution commercial CD from Papua New Guinea, would simultaneously make two very strong statements: the contents were equally environmental and human sounds, and the lead composer and performer was a village woman. 
K.M: And how is it now?

S.F: I think it is now different in several ways. There is no oil in Bosavi, and there are no local logging contracts. The men who leave, who would have perhaps become distinguished in ceremonial life in earlier years, now want to go into politics, business, or teaching. The royalty money from the CD for all these years has expanded the school opportunities for both men and women. We have women who are now university graduates, who are coming back and living in the villages and working as teachers in the schools. People have clearly a capitalist, business relationship to the CD and what it did. Ulahi is somebody who brought both money and recognition to Bosavi; people are proud of her. Of course, now she is an elder too. When I went back to work with her in 2018 young guys wanted to join us in the forest; I could tell they were impressed by her knowledge. I also organized events with schoolchildren: they would listen to her songs and draw song maps. The film uses one made by a third grade student. On the most recent return, December 2019 and January 2020, the new film was screened for the communities involved. We also worked on a follow-up film about political, economic, and generational changes, to be called New Voices of the Rainforest.

K.M: Going back to the concept of acoustemology: it becomes clear that representing acoustic knowledges is a creative endeavour. One noticeable thing is that your post $2000 \mathrm{CD}$ s and films like The Time of Bells series ${ }^{9}$ or your work on jazz in Ghana ${ }^{10}$ have de-emphasized the standalone text. Where do you see this going in the future? Are you planning other types of experiments?

S.F: Two things about that. My experience in Ghana was very profound. I didn't go there to do research, but then I found people who I really admired and enjoyed. In the terms of Rouch, we created a "seminal friendship." They wanted their work well documented, and to get paid for it. Fifteen years later there are five one-hour films and twelve CDs. Many were completed before I wrote a companion monograph. That project was a way of taking a new step forward, and of course it's influencing what I'm doing in Bosavi now with these new films to

9. Feld S., 2004, 2005, 2006, The Time of Bells, 4 volumes, VoxLox.

10. Feld S., 2012, Jazz Cosmopolitanism in Accra. Five musical years in Ghana, Duke University Press, With companion CD \& DVD, Durham. 
expand the representational world of the earlier monograph, articles, dictionary, and CDs.

My newest project in progress is a DVD titled Acoustemology. It consists of four lectures, each less than one hour. It's me performing them with my voice, accompanied by images, sounds, videoclips, and graphics. It's a way to acknowledge how much I owe to my audiences, to my listeners. There will be nothing to read. Just the disc to play, to watch and listen as I try to combine insights from theory and my research in Ghana, Papua New Guinea, Europe, and Japan. So for 2020 I'll be working both on that DVD, and on editing the New Voices of the Rainforest film. 